\title{
A koronáriabifurkációk percutan kezelési lehetöségei: a simplified highway-technika
}

\author{
Katona András, Ungi Imre, Sasi Viktor, Thury Attila
}

\author{
Szegedi Tudományegyetem, Általános Orvostudományi Kar, Szeged
}

Levelezési cím:

Dr. Katona András, e-mail: kabandi81@gmail.com

\begin{abstract}
Bevezetés: Percutan koronáriaintervenciót $(\mathrm{PCl})$ gyakran bifurkációt érintő szükületekben végzünk. Jelen ajánlás szerint a föág stentimplantációja az elsődleges, azonban emiatt az oldalágat tekintve sok esetben szuboptimális procedurális eredményt kapunk. Ennek megelőzésére több technikát javasolnak; az általunk ismertetett új eljárás alkalmazásával nyert tapasztalatok feldolgozása jelenleg is folyik részlegünkön.

Módszerek: Prospektív módon gyüjtjük az ún. „simplified highway-technika” (SHW) alkalmazásával kezelt betegeink adatait. E technikát a legalább 2,0 mm-es átméröjü és $20 \%$-os ostialis szükületet mutató oldalágak esetén alkalmazzuk. Jelen munkánkban retrospektív módon elemeztük az angiográfiás jellemzőket, a beavatkozás procedurális szövődményeit.

Eredmények: 2014. október és 2017. november között 181 SHW PCl-t végeztünk 180 betegben, 36 esetben akut koronáriaszindrómában, 145 esetben elektív helyzetben. A kezelt bifurkáció megoszlása: 6,6\% bal közös fötörzs, $59,2 \%$ bal mellsö leszálló ág-diagonális oldalág, 27,6\% circumflex artéria-marginális ág, 6,6\% disztális jobb koronáriabifurkáció. Az esetek többségében sikerült az eredetileg tervezett föág 1 stent stratégiát követni, de 19 esetben az oldalágba 2. stent beültetésére volt szükség. Ez 8 esetben „T and protrusion”, 7 esetben „culotte”, 2 esetben „reverse crush” és 2 esetben „mini stent-crush” kiegészítő stentelést jelentett. Utóbbi az SHW-technika által egyedüliként adódó lehetöség; a föágstenten kívül maradt „csatornán" szükség esetén lehetséges az oldalágba kivezetni a második stentet. 1 esetben azonban az oldalág az SHW-technika alkalmazása ellenére szubokkludálódott, azt tágítani nem lehetett.

Megbeszélés: A bemutatott SHW-technika előnye a $6 \mathrm{~F}$ kompatibilitás és az oldalág elérhetöségének szinte maradéktalan biztositása. Ugyanakkor elöfordult, hogy kiegészítő stentimplantációra volt szükség. Ez felhívja a figyelmet arra, hogy az oldalágvédési technikákat tovább kell tökéletesíteni.
\end{abstract}

Kulcsszavak: bifurkáció, stent, PSBS, crush, culotte

Simplified highway technique for the treatment of bifurcation lesions - initial experiences in our center

Introduction: Bifurcations often involved in percutan coronary interventions ( $\mathrm{PCl}$ ). According to current guidelines, one stent technique is the gold standard, thus it means suboptimal result in the side branch. Numerous techniques are suggested to protect the side branch however none of them is perfect. A new method is described below, with our first experiences and early data. Methods: Data of the patients who are treated with this "Simplified Highway Technique" (SHW) are collected prospectively. Inclusion criteria is at least $2 \mathrm{~mm}$ diameter of the side branch with a minimum of $20 \%$ ostial diameter stenosis. Angiographic features and procedural complications analysed retrospectively.

Results: Between 2014 October and 2017 November 181 bifurcation were treated with SHW in 180 patients, 36 were cut coronary syndrome (ACS) and 145 elective case. Distribution of these bifurcations: $6.6 \%$ left main coronary artery (LMCA), $59.2 \%$ left anterior descending-diagonal (LAD - diagonal), $27.6 \%$ ramus circumflex - obtuse marginal (CX - OM), $6.6 \%$ distal right coronary (RCA). Most of the cases the planned one stent strategy provided satisfactory result, but in 19 cases a second stent implantation in the side branch were needed. It means "crush" in 4 cases", "T and protrusion" in 8 cases, "culotte" in 7 cases. "bail-out" crush is a unique advantage of this method, as a "service channel" remains outside of the main branch stent, which gives the possibility to deploy a stent "under" the main branch stent before proximal optimalisation (POT). This was not possible only in 1 case, where this channel collapsed and impossible to redilatate it.

Discussion: Advantage of this SHW technique is the simplicity and fully controlled side branch availability in $6 \mathrm{Fr}$ guiding catheters. In spite of this primary one stent technique, delivery of a second stent is easy. Of course the need of a second stent due to a dissection draws the attention on imperfection of current side branch protection techniques.

Keywords: bifurcation, stent, PSBS, crush, culotte

A kézirat 2020. 07. 25-én érkezett a szerkesztőségbe, 2020. 08. 28-án került elfogadásra. 


\section{Bevezetés}

Koszorúér-betegség és a bifurkációt érintő szúkületek

A koszorúér-szükületek ateroszklerózis talaján alakulnak ki. Ezen lassú, progresszív folyamat eredményeként plakkok keletkeznek az artériákon belül, amelyek szűkítve a lument, csökkentik a vér átáramlását, ezzel miokardiális iszkémiát okozva (27).

A bifurkációk az ateroszklerózis predilekciós helyei (1. ábra), mivel ezen a területen egyedi véráramlási minták hatására örvényszerü recirkulációs zónák keletkeznek, amelyek elősegítik a plakkok felépülését. A bifurkációs régiók hisztopatológiai vizsgálatai alapján a plakk lokalizációja szoros összefüggést mutat a helyi endothelialis nyíróerő-mintákkal (10).

Ennek értelmében bifurkációs szükületek gyakran az epikardiális koszorúerek elágazásainál (oldalágak eredéséhez közel) alakulnak ki. Az adott szükület kezelésének módját számos tényező befolyásolja: a beteg tünetei, általános állapota, rizikófaktorai, bal kamra funkciója, funkcionális tesztek eredményei. Ez utóbbi az oldalág klinikai jelentőségét is megadja, ugyanakkor az oldalág angiográfiás mérete, hossza, lokalizációja, eredési szöge és a lézió komplexitása is meghatározza az intervenciós kardiológus döntését. Mindezek végeredményeként a ,jelentős oldalág” egyszerüen kifejezve az, amit nem akarunk elveszíteni, hogy a föág intervenciója után se alakuljon ki eredési szűkület, vagy áramláscsökkenés (16).

A bifurkációs léziók feloszthatók a szignifikáns lumenszükület helye alapján, amely érintheti, vagy a fő-, vagy az oldalágat, de jelen lehet egyszerre mindkettőben is (Louvard és Medina, 2015). Valódi bifurkációs léziónak nevezzük azon szükületeket, ahol a főág proximális és/ vagy disztális szegmense mellett az oldalág eredésében is legalább $50 \%$-ot meghaladó szükület van (2. ábrán láthatók az 1,1,1; 1,0,1; 0,1,1 léziótípusok).

\section{Koszorúér-stentelési technikák a bifurkációs szúkületek kezelésében} A provizionális oldalágstentelés (PSBS) Jelenleg az EBC által előnyben részesített eljárás a bifurkációs léziók PCl-je során a főág stentelése proximális optimalizációval és a provisional side branch stenting (PSBS) (13). A főág proximális szegmenséből a disztális szegmens felé helyezik ki a stentet, miközben az oldalágban egy másik vezetődrótot hagynak („kiszorított”, angolul jailed-nek nevezett oldalágdrót)

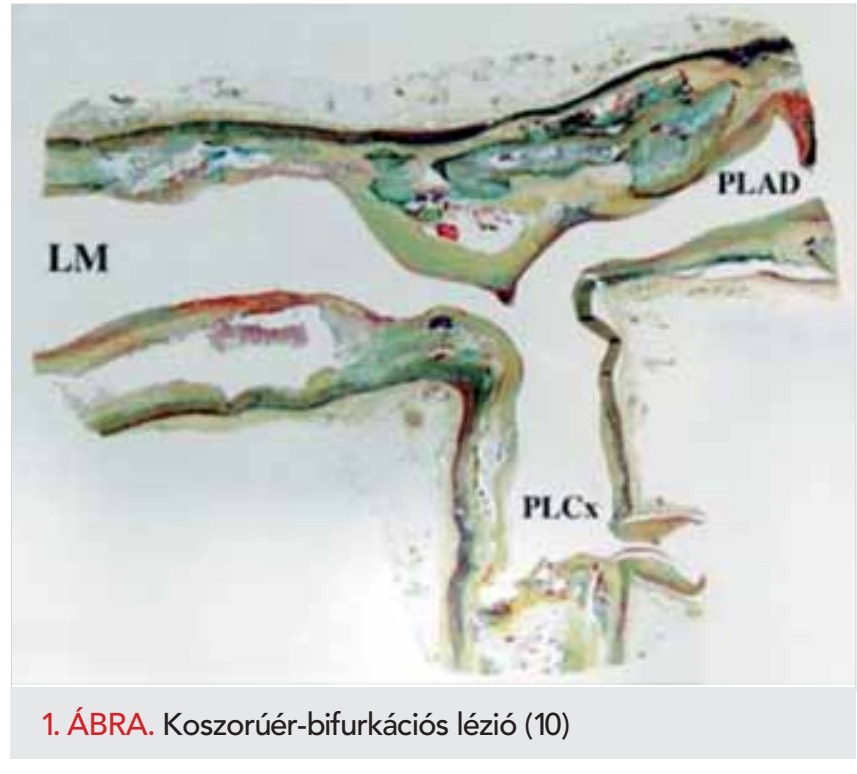

(3. ábra). A stent méretének kiválasztása 2016-ig vita tárgyát képezte, a jelenleg elfogadott álláspont alapján a disztális főág átmérőjével legyen egyező (13).

A PSBS-eljárás előnye, hogy az egy stentes megoldás szükség szerint átkonvertálható „bail-out” két stentes

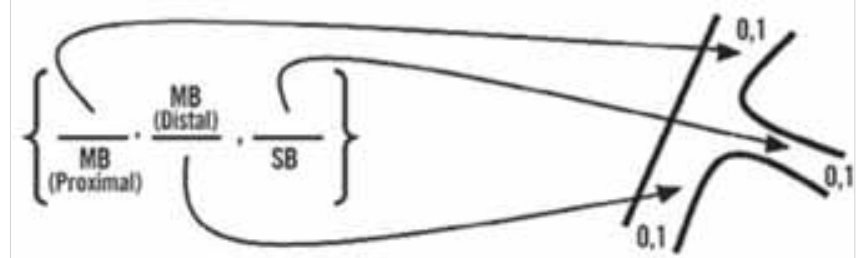

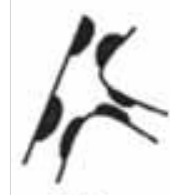

$1,1,1$

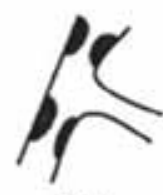

$1,1,0$

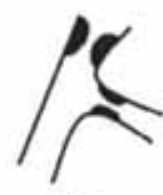

$1.0,1$

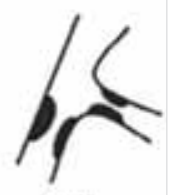

$0,1,1$
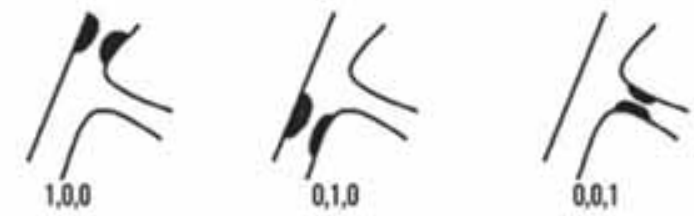

2. ÁBRA. Medina klasszifikáció. Szignifikáns szűkület hiányában mindegyik szegmens 0 értéket képvisel, $50 \%$-ot meghaladó szükület jelenléte esetén ez az érték 1. A 0-val vagy 1-es értékkel jelölt három szegmens sorrendje a következő: proximális főágszegmens, disztális főágszegmens, oldalág, az értékeket vesszővel választjuk el

\section{Rövidítésjegyzék}

ACS = akut koronáriaszindróma (acute coronary syndrome); EBC = European Bifurcation Club; HW = highway-technika; JBP = jailed ballon protection technika; JSB = jailed semi-inflated ballontechnika; $\mathrm{KBI}=$ kissing ballon infláció; $\mathrm{LAD}=$ bal mellső leszálló ág (left anterior descending); LCx = bal circumflex artéria (left circumflex artery); LM = bal közös fötörzs (left main); MJB = modified jailed balloon protection technika; NC = nem táguló, „kemény” (non-compliant); PCI = percutan koronáriaintervenció; POT = proximális optimalizációs technika; PSBS = provízionális oldalág-stentelés (provisional side branch stenting); SHW = simplified highway-technika; TAP = T and protrusion; TIMI = thrombolysis in myocardial infarction 


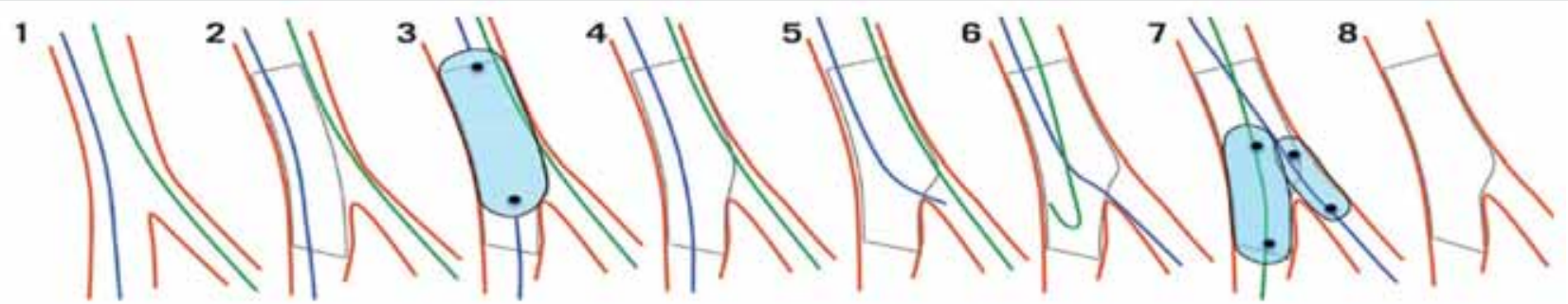

3. ÁBRA. Bemutatja a PSBS lépéseit (13). 1. Első lépésként vezetődrótot juttatunk mind a fő-, mind az oldalágba; 2 . majd a főág stentelését követően 3. proximális optimalizációt alkalmazunk, a 4. lépésnél a stent megfelelő pozícióban van; 5,6 . ha az operatőr úgy véli, hogy az oldalág nem intakt, akkor újradrótozást követően, a stent celláin átjuttatva a drótot; 7. kissing technikával rövid, NC-ballonok szimultán inflációjával segíti az oldalág átjárhatóságát, úgy, hogy 8. elkerülje az oldalág disszekcióját és a stent torzulását

(pl. „T and protrusion” vagy „culotte”) technikává (3. ábra). A PSBS, illetve szükség esetén a 2 stentre való kiegészítés is $6 \mathrm{Fr}$ kompatibilis.

A jailed-drót szerepét is hangsúlyoznunk kell. A föág stentbehelyezését követően az oldalág ostiuma szükülhet (sokszor ezt is ,jail-nek" nevezik) a föág stentexpanziója miatt, akár el is záródhat. A drót az oldalágban maradva ugyanakkor markerként szolgál, illetve a béta-szög megtartásával segíti az operatőrt, hogy a föágon keresztül új drótot tudjon bevezetni az oldalágba. A proximális referenciának megfelelő méretủ non-compliant ballonnal végzett optimalizációt (POT) követően a föág cellái az oldalág felé nyílnak, ez is elősegíti egy harmadik drót átjuttatását az oldalág ostiumba (14).

A PSBS relatív hatékonyságát bizonyítja, hogy az esetek $80-90 \%$-ában elegendő egy stentet behelyezni a föágba, (15), amellyel hasonló eredményeket érhetünk el, mint más, sokkal komplexebb technikákkal. Randomizált vizsgálatok alapján ez az eljárás lett a bifurkációs szükületek kezelésének aranystandardja (19).

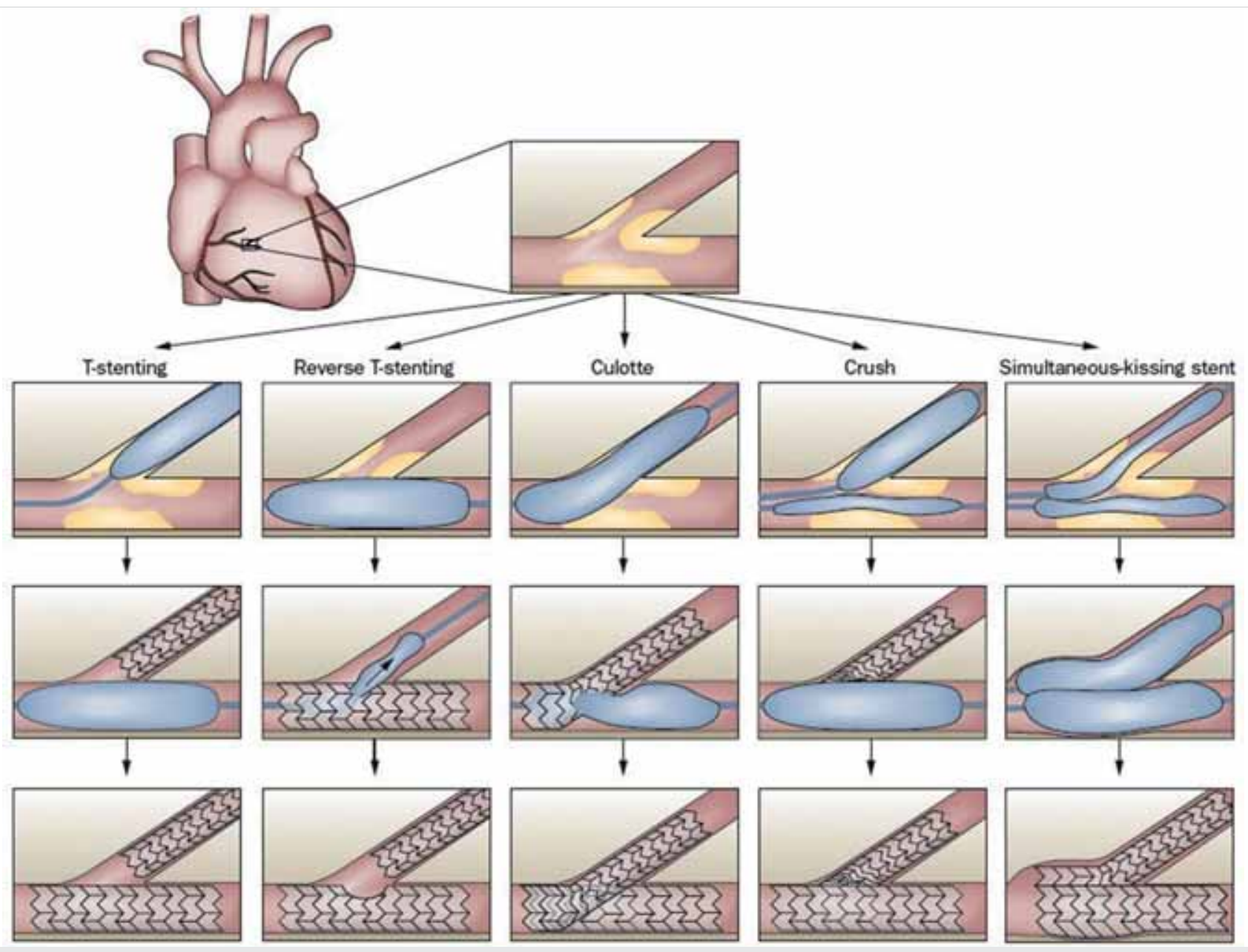

4. ÁBRA. A tervezetten két stentes stratégiák vázlata (http://www.medscape.org/viewarticle/727014_2) 

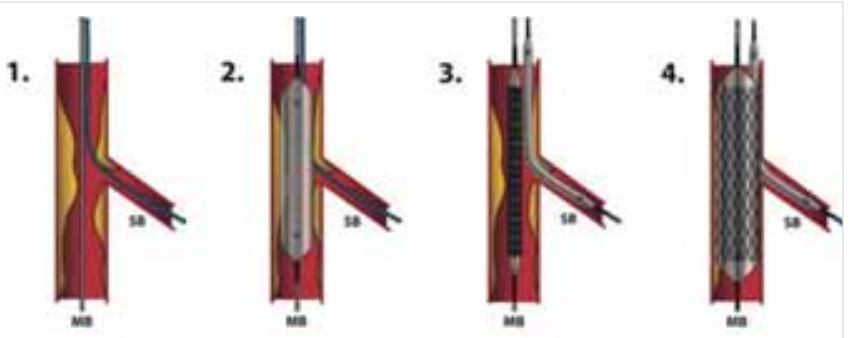

5.
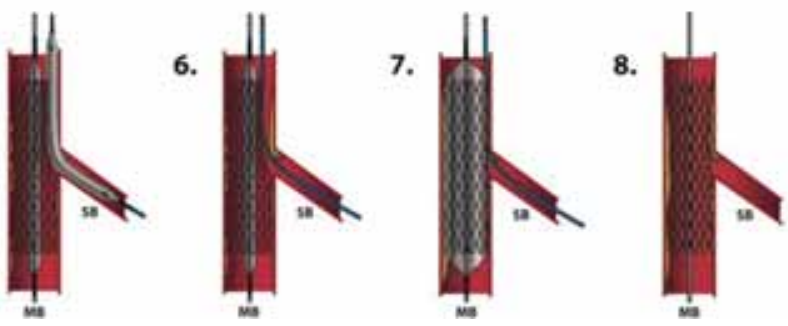

5. ÁBRA. Jailed balloon protection technika (JBP) lépései: 1. A föágba $180-300 \mathrm{~cm}$-es, az oldalágba $185 \mathrm{~cm}$-es vezetődrótot juttatnak; 2. A főágba standard, semi-compliant ballont; 3. Az oldalágba adekvát hosszúságú ballont helyeznek, úgy, hogy az túlérjen az ostiumon, majd standard koszorúér-stentet juttatnak a főágba, úgy hogy az lefedje a léziót. Az oldalág proximális markerét a főág stenttől $~ 2 \mathrm{~mm}$-rel proximálisabban helyezik el, hogy elkerüljék a beszorulást; 4. Ezt követően a főágstentet nominális nyomással inflálják, ekkor az oldalágdrót és ballon „jail"-be kerül; 5 . Ha az oldalágban megfelelő az áramlás (TIMI 3), az oldalágballont alacsony nyomással (<3 atm) fújják fel, majd az oldalágballont és drótot eltávolítják (ha az operatőr szerint szükséges, akkor az oldalág-vezetődrótot a helyén hagyva a főág stentoptimalizációt követően távolítja el. Ha az áramlás csökkent (<TIMI 3) az oldalágban rutin angioplasztikát végeznek a ballon és drót eltávolítása előtt; 6 . Az oldalágdrótot és ballont eltávolítják mialatt a főágballont mindvégig a stentben parkoltatják; 7. A főágstentet a megfelelő pozíció elérése érdekében ismételten expandálják; 8. Záró angiográfián ellenőrzik az eredményt (26)

\section{Oldalág-elzáródás - definíció és kezelés}

Számos tényező vezethet oldalág-elzáródáshoz, mint a plakk shift, carina shift, lapossá váló béta-szög a főág stentelését követően (12). Az oldalág proximális részének disszekciója, spazmusa is hozzájárulhat az oldalágvesztéshez, azonban arról még nincs elegendő adat, hogy milyen tényleges predikciós tényezők járulnak hozzá a PSBS általi oldalágvesztéshez (23). Az oldalág jail gyakrabban fordul elő nagyméretű, erősen meszes, súlyos ostiumszükülettel rendelkező oldalág esetén (23). Teljes elzáródás gyakrabban fordult elő valódi bifurkációs lézióknál és kisebb oldalágátmérőknél. Az oldalág teljes okklúziója nagy kihívást jelent az operatőr számára, mivel az oldalág újradrótozása és az áramlás megóvása is nehézségeket rejt magában a föág stentelése után (18). A disztális kaliberhez méretezett föágstent proximális edge-nél nem a tökéletes appozíciólehetőség van a stent mögé vezetni ballont az eredeti, jailed dróton, majd ezt a „teret” egyre nagyobb ballonokkal feltágítani. Innen pedig két lehetőség az „invertált crush" stentelés (20), amikor stentet helyezünk ki az oldalág felé végleg crusholva a főágat, vagy csak anynyira tágítjuk fel a stent mögötti „rést”, hogy ezen ki tudjunk juttatni egy stentet az oldalágba, majd azt crusholni a mindvégig fóágban hagyott ballonnal (,reverse crush”). Az 4. ábra a tervezetten két stentes stratégiákat, komplex kezeléseket összegzi.

\section{Hogyan előzzük meg az oldalág elzáródását? Az egyes technikai lehetőségek}

Mint minden más helyzetben, a medicinában, mindig jobb a prevenció, mint később orvosolni a komplikációkat. Célunk bemutatni a különböző oldalágvédési technikákat a bifurkációs szükületek provisional side branch stentelése (PSBS) során.

\section{Jailed balloon protection technika (JBP)}

Burzotta 2010-ben közölte az akut oldalág-elzáródás megelőzését célzó új technikai megoldását ,jailed balloon protection” (JBP) néven (4). Ennek során a „provizionális T-stentelést” módosították úgy, hogy már nemcsak egy vezetődrótot juttattak az oldalágba, hanem arra egy ballont is pozícionáltak (5. ábra). Ezt azonban csak akkor inflálták, ha az oldalág okkludálódott vagy abban megromlott az áramlás (<TIMI 3).

\section{Jailed semi-inflated balloon technika}

2015-ben egy török munkacsoport dolgozta ki a ,jailed semi-inflated balloon technique" (JSB) néven ismert eljárást (6. ábra). Ők a stenttől kissé proximálisabban
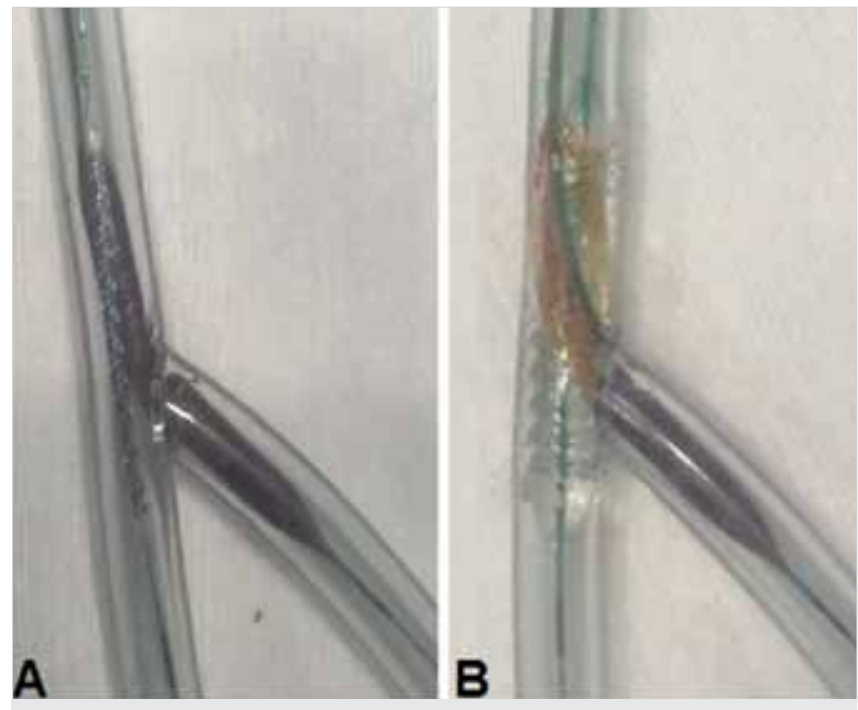

6. ÁBRA. Jailed semi-inflated balloon technika (JSB) tesztelése. (A) Az oldalágballon proximális markere és a főágstent proximális vége ugyanazon magasságban van, az oldalágballoninfláció alacsony nyomással (3 atm) történik; (B) a főágstent ballonfelfújását követően a jailed oldalágballon proximális része (a föágstent mögött látható kontrasztanyag) összenyomódott, az oldalág ostiumától disztálisan hiperinfláció jött létre (6) 
indított, az oldalág átmérőjének megfelelő méretű ballont pozícionáltak az oldalágba (6). A JSB-eljárás a JBP-technika továbbfejlesztett változatának felel meg. Az intervenció során az oldalágballont alacsony nyomással a főágstent kihelyezésével egy időben és proximálisan egyszintben fújják fel, így ezen ballon teljesen „kitölti” az oldalág ostiumát, amellyel védi az oldalágat a plakk, illetve carina áttolódásából származó elzáródástól (6).

\section{Highway-technika}

A PSBS-technika módosításával a főágstent felfújásával egy időben egy ballont pozícionálnak az oldalágba, úgy, hogy az proximálisan túlnyúljon a föágstenten és lefedje az oldalág ostiumát, majd a főág-stentballont és az oldalágballont szimultán inflálják (a 7. ábrán láthatók a HW lépései). A stentballont leengedik és eltávolítják, míg az oldalágballont leengedve a helyén hagyva egy harmadik drótot visznek a disztális főágszegmensbe. Ezután eltávolítják az oldalágballont és -drótot, majd az eredeti fóágdrótot a stent celláin keresztül az oldalágba juttatják. Az oldalágballont felfújják a stentstrutok kitágítása céljából. Majd ezt a ballont a helyén hagyva, egy megfelelő méretủ ballont visznek a harmadik vezetődróton keresztül a főágstentbe és magas nyomáson inflálják. Végül kissing balloninflációval (KBI) fejezik be az eljárást. Amennyiben szükséges, ekkor van lehetőség az oldalágstent kezelésére, amely után ismételt KBI következik. A highway-technika alkalmazását számos előnye miatt kedvezőnek találták a 30 napos klinikai eredményeket tekintve is (5).

Ha súlyosan ateroszklerotikus oldalág jelenléte kizárható, akkor nem javasolt azt előtágítani, mivel magasabb arányban alakulhat ki disszekció benne, amelybe egy új vezetődrót levezetése az állumen propagációjához, illetve az ebben való stentimplantáció oldalágvesztéshez vezethet. A HW során a szimultán infláció miatt a fóág proximális szegmensében a nem teljes stentexpanzió következtében deformált stent celláin keresztül nehézkes az oldalág újradrótozása (POT). Véleményünk szerint a HW túl komplex, kevésbé optimális eljárás az oldalágáramlás fenntartására a főág stentelését követően. Ez a fő oka annak, hogy intézetünkben ennek a módosított változatát dolgoztuk ki és kezdtük el alkalmazni, amelyet simplified highway-technikának (SHW) neveztünk el.

\section{Célkitúzés}

Célunk az volt, hogy a HW módosításával, majd ennek a szignifikáns bifurkációs koszorúér-szükületek esetében prospektív alkalmazásával kapott procedurális eredményeket gyưjtsük és statisztikailag vizsgáljuk ezen eljárás hatékonyságát.

A procedurális angiográfiás eredmények értékelésével meghatároztuk az oldalágvédés eredményességét. Ez-
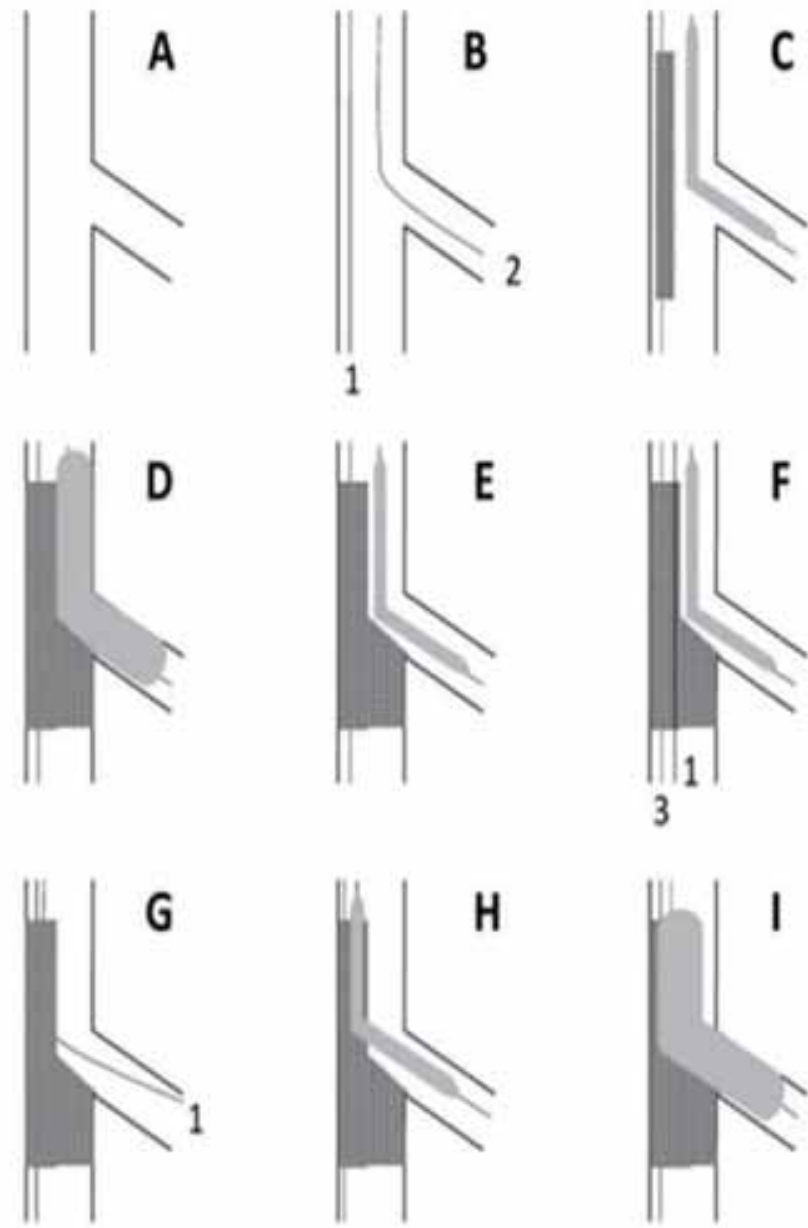

3
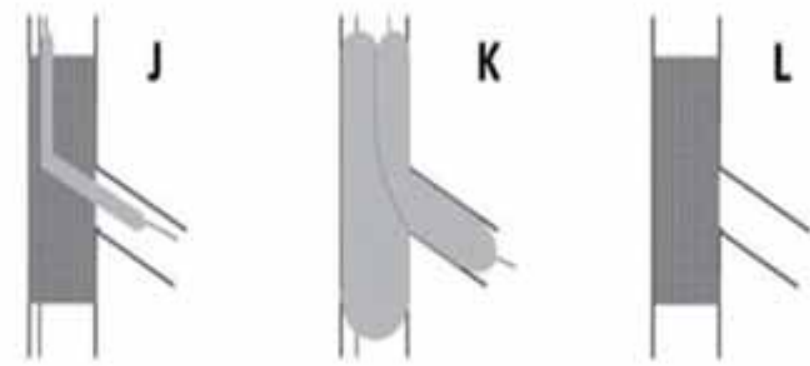

7. ÁBRA. Highway-technika (HW) alkalmazásának illusztrációja (5)

zel párhuzamosan próbáltuk ezen új stentelési eljárás lehetséges hátrányait is feltárni.

\section{Betegek és módszer}

\section{Betegek kiválasztása}

Általános bevonási kritériumként a szignifikáns bifurkációs szükületeket vettük, amely a főág legalább 50\%os szegmens szükülete mellett a minimum $2 \mathrm{~mm}$-es átmérőjü, legalább 20\%-os oldalág ostium szűkületét jelentette. 
A típus: Kontrasztadás közben enyhe telödési hiányként ábrázolódó terület a koronáriák lefutásán belül, de kis kontraszttapadással vagy anélkül

B típus: Kontrasztadás közben párhuzamos lefutású, vagy dupla lumen telödik fel a normál lefutáson belül, közöttük telödési hiánnyal, de kis kontraszttapadással vagy anélkül

C típus: A disszekció az érpálya lefutásán kívül is

megjelenik és ott perzisztál a lumenből való kimosódás után is („extraluminális sapka”)

D típus: Spirális telödési rendellenesség a lumenben, amely gyakran kontrasztpangással jár a fals lumenben („,barber shop” jel)

E típus: Új keletủ telődési kiesés a lumenen belül

F típus: Teljes elzáródással járó disszekció, ahol a disztális lumen anterograd nem telödik

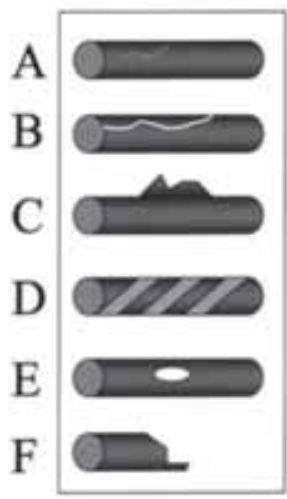

8. ÁBRA. Ballontágítás okozta disszekciótípusok; http:// www.medscape.com/viewarticle/490976_2

Kizáró kritériumként a tervezetten 2 stentes stratégiák: az oldalág súlyos, meszes stenosisa ( $\geq 75 \%$ átmérőszűkület), a proximális szegmenésnek hosszú, legalább 5 mm-es szignifikáns szükülete vagy súlyos tortuozitása szerepelt.

Procedurális sikerként könyveltük el a főág stentelt szegmensén belüli maximum 30\%-os (a stent maga maximálisan $20 \%$-os alulexpanziót mutasson) reziduális szükület meglétét, és a föágban és az oldalágban a TIMI 3 áramlást, valamint az áramlást akadályozó diszszekció hiányát (8. ábrán a disszekció különböző típusai láthatók).

\section{A simplified highway-technika leírása}

A SHW-technika alkalmazása minden esetben az operatőrre volt bízva. A betegek kiválasztásánál figyelembe vettük a szignifikáns bifurkációs szűkületeket, a $90^{\circ}$-nál nagyobb bifurkáiós szöget és azon anatómiai variációkat és léziómorfológiát, amelyek nehezítették az oldalághoz való hozzáférést. Az SHW egy standardizált eljárás, amely az intézetünkben került fejlesztésre. A 9. ábra részletezi a technika lépéseit, a 10. ábra angiográfiás képeken ábrázolja az eljárást.

A procedúra során leginkább radiális, ritkábban femorális behatolást alkalmazva 6-7 Fr vezetőkatétert alkalmazunk. Első lépésként vezetődrótot juttatunk mindkét ágba. A főág előtágítását szükség esetén standard semi-compliant ballonnal végezzük.

A: A főágba a disztális szegmensnek megfelelő méretű és adekvát hosszúságú stentet helyezünk, míg az oldalágba egy kissé alulméretes, az érkaliber 75\%-a körüli semi-compliant ballont juttatunk, úgy, hogy az a föágstent proximális szélénél vagy attól proximálisabban kezdődjön és az oldalágig érjen. Ennek oka egyrészt, hogy az oldalágballon proximális összenyomásával a disztális rész hiperinflációja ne okozzon barotraumát, valamint megfelelő mértékben védje az ostiumot a plakk, vagy carina áttolódástól. Ez a proximális elhelyezés pedig a ballon stent mögé szorulását előzheti meg.
B, C: A stentet nominális, az oldalágballont pedig alacsony nyomással (4-6 atm) szimultán fújjuk fel, majd engedjük le. A jail-be került, részben felfújt ballon megakadályozza a plakk, illetve carinaáttolódást, mivel szinte teljesen „kitölti” az oldalág ostiumát.

D: Ezután a föág ballonját helyben hagyva, az oldalágballont eltávolítva kontroll angiográfián ellenőrizzük az oldalág intaktságát. Ekkor, ha az oldalág elzáródott vagy áramlást csökkentő magas fokú disszekció alakul ki, lehetőségünk van ezen az „úton” az egy stentes módszert két stentessé alakítani; vagyis az oldalág irányában hagyott „-csatornán” keresztül levezethető a megfelelő méretű stent, amelyet a főág stentjében hagyott ballonnal tudunk crush-olni.

E: Ha nincs nagyobb fokú reziduális szükület vagy csökkent áramlás, a főágból a stentballont eltávolítva és a proximális érkalibernek megfelelő méretű NC-ballonra cserélve nagynyomású proximális opti-
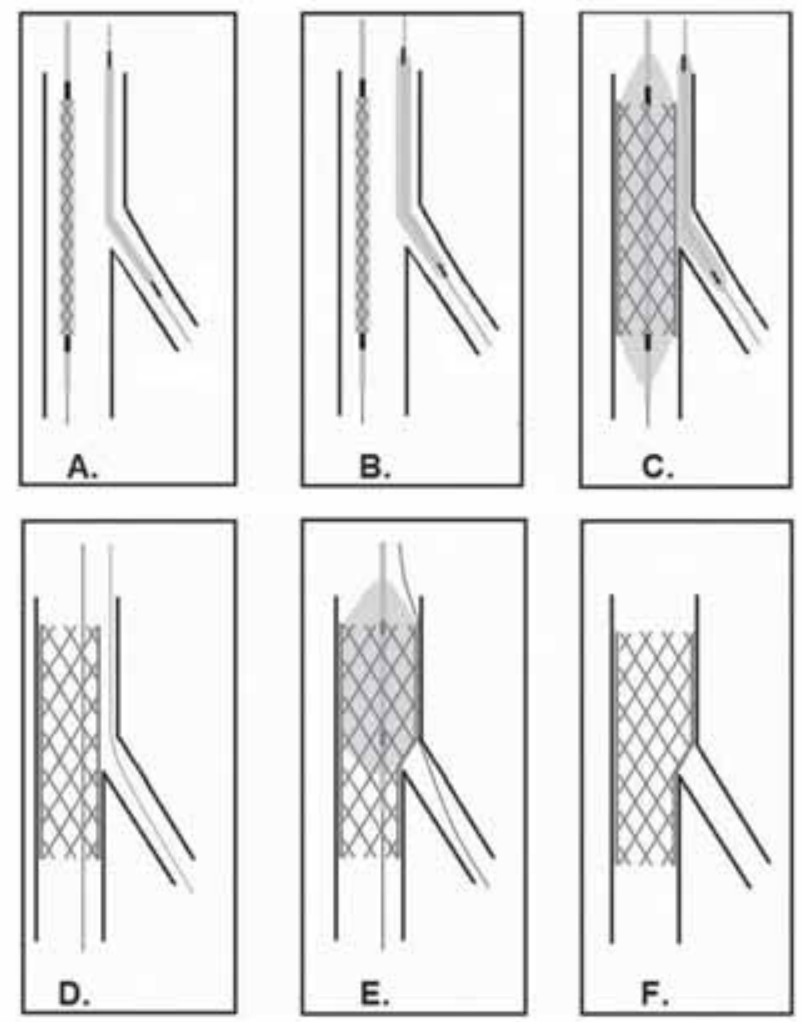

9. ÁBRA. Az SHW-technika lépései: A: Előtágítást követően mindkét ágba standard vezetődrótot juttatunk. A főágba a disztális referenciának megfelelő méretű és adekvát hosszúságú stentet viszünk, míg az oldalágba egy kissé alulméretes, az érkaliber 75\%-a körüli átmérőjü, de elég hosszú ballont pozícionálunk, amelynél fontos, hogy a stent proximális markerénél vagy attól proximálisabban kezdődjön és az oldalágig érjen. B-C: Szimultán inflációt követően. D: kontroll angiográfián ellenőrizzük az oldalág intaktságát, majd ha ez intakt. E: POT-tal. F: a drótok és a ballon eltávolításával és záró angiográfiával fejezzük be az eljárást 


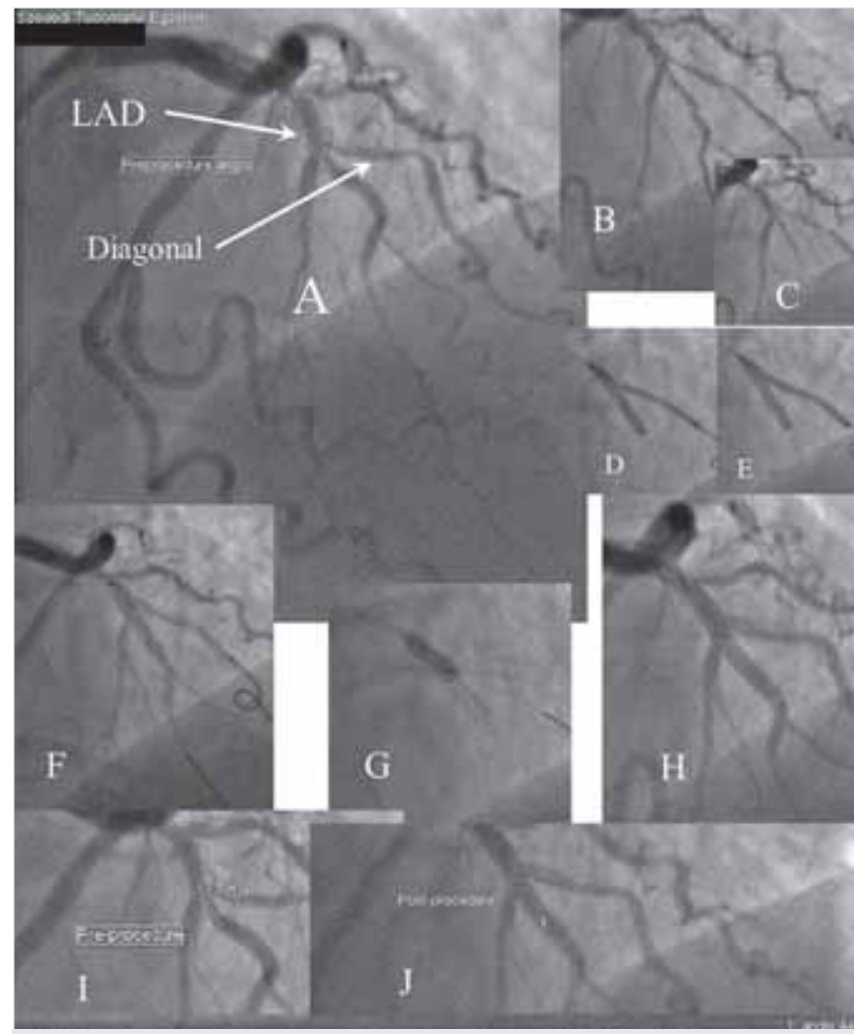

10. ÁBRA. A: Disztális bal mellső leszáló ág-diagonális oldalág-bifurkációs szűkülete. B: Mindkét ág drótozását követően a disztális bal mellső leszálló ágba stentet, a diagonális oldalágba ballont pozícionálunk, C: amelynek proximális markere a stenttől kissé proximálisabban helyezkedik el. D-E: Szimultán inflációt alkalmazunk. F: a főágban hagyott stentballonnal kontroll angiográfiát végzünk. G: POT-tal fejezzük be az intervenciót. H: Záró angiográfián látható a szinte reziduális szűkülettől mentes bifurkáció, az oldalág B-típusú disszekciójával, ami az áramlást nem befolyásolta: TIMI 3 áramlás a záró angiogrammon. $1-\mathrm{J}$ : Az azonos projekcióban mért béta-szög pre- és posztprocedurálisan is lényegében változatlan maradt. LAD: bal mellső leszálló ág

malizációval, majd a drótok eltávolításával fejezzük be az eljárást.

F: Záró angiográfia sematikus ábrázolása (9. ábra).

\section{Statisztika}

A statisztikai számításokat a MedCalc ${ }^{\circledR}$ 13.3.3. verziójával végeztük. A folyamatos változókat az átlag \pm standard deviációval fejeztük ki, a kategorikus változókat százalékokban határoztuk meg. Összehasonlítottuk a pre- és posztprocedurális angiográfiás jellemzőket kétmintás T-próbát használva. Statisztikailag szignifikánsnak tekintettük az eredményeket ha a p<0,05.

\section{Eredmények}

Betegpopuláció, klinikai és angiográfiás jellegzetességek

A beavatkozások 2014. október 1-jétől 2017. november 30-ig zajlottak. Ezalatt 181 simplified highway percutan

\begin{tabular}{|c|c|}
\hline \multicolumn{2}{|c|}{ 1. TÁBLÁZAT. Betegek klinikai jellegzetességei ( $n=181)$} \\
\hline Kor (év) & $68,4 \pm 8,5$ \\
\hline \multicolumn{2}{|l|}{ Nem $(\%)$} \\
\hline Férfi & $131(72,4)$ \\
\hline Nő & $50(27,6)$ \\
\hline Magas vérnyomás (\%) & $166(91,7)$ \\
\hline Cukorbetegség (\%) & $64(35,4)$ \\
\hline Hyperlipidaemia (\%) & $156(86,2)$ \\
\hline \multicolumn{2}{|l|}{ Erek érintettsége (\%) } \\
\hline Egy ér & $62(34,2)$ \\
\hline Két ér & $74(40,9)$ \\
\hline Három ér & $45(24,9)$ \\
\hline \multicolumn{2}{|l|}{ PCl-indikáció (\%) } \\
\hline Stabil angina & $145(80,1)$ \\
\hline Instabil angina/NSTEMI & $21(11,6)$ \\
\hline STEMI & $15(8,3)$ \\
\hline
\end{tabular}

PCI: percutan coronariaintervenció, NSTEMI = nem ST-elevációs miokardiális infarktus, STEMI = ST-elevációs miokardiális infarktus

koronáriaintervenciót végeztünk 180 betegben, 36 esetben (19,9\%) akut koronáriaszindrómában, 145 esetben $(80,1 \%)$ elektív helyzetben. Az 1. táblázat összefoglalja a betegek általános klinikai jellemzőit, amely a nemzetközi átlagnak felel meg.

A 2. táblázat foglalja össze az angiográfiás és procedurális jellegzetességeket. Radiális behatolást alkalmaztunk az esetek többségében (84,5\%). Fontos volt a 6F kompatibilitás, amit a procedúrák nagy részénél sikerült megvalósítani $(77,4 \%)$, azonban néhány betegnél 7F vezetőkatétert kellett alkalmaznunk, akár radiális behatolásból is. A léziók lokalizációja a következőképpen alakult: a bal közös törzs (LM) 6,6\%-ban, a bal mellső leszálló ág (LAD) - első diagonális oldalág 40,9\%-ban, a LAD - második diagonális oldalág 18,3\%-ban, a bal circumflex artéria - obtus marginalis ág 27,6\%-ban és a disztális jobb koszorúér (PD-PL) 6,6\%-ban volt érintett. Összesen 51 betegnek (28\%) volt valódi bifurkációs szükülete (Medina 1,1,1 vagy 1,0,1 vagy 0,1,1 léziók). $70^{\circ}$ alatti, lapos béta-szög az esetek 65,2\%-ában fordult elő. Preprocedurálisan TIMI 3 áramlás a főágban $79,6 \%$-ban, az oldalágban 76,8\%-ban volt jelen. A főágat $166(91,7 \%)$, az oldalágat $11(6,1 \%)$ esetben tágítottuk elő. A beavatkozás (a vezetőkatéter felvezetése után számítva) átlagos időtartama 39,6₫23,8 perc volt.

\section{Procedurális eredmények, angiográfiás elemzés}

A 3. táblázat foglalja össze a közvetlen procedurális eredményeket. A beavatkozás sikerrátája 99,5\%-os volt. A procedúrát befejezve a betegek többségében TIMI 3 áramlás ábrázolódott, mind a fő- mind, az oldalágban. 7 esetben (3,9\%) a föág stentelését követően az oldalág eredésénél disszekció jelentkezett. További 12 esetben (6,6\%) az oldalág eredésénél masszív, 75\%-ot 
2. TÁBLÁZAT. Kezelt léziók procedurális és angiográfiás jellemzői $(n=181)$

Léziólokalizáció (\%)

Disztális bal közös fötörzs $12(6,6)$

LAD-D1 $74(40,9)$

LAD-D2 $33(18,3)$

Bal circumflex artéria-obtus $\quad 50(27,6)$

marginális ág

Jobb koronária-PD-PL $12(6,6)$

Bifurkáció-csoportosítás (\%)

Medina $1,1,1 \quad 26(14,4)$

\begin{tabular}{l|l} 
Medina $1,1,0 \quad 41(22,7)$
\end{tabular}

Medina $1,0,1 \quad 20(11,0)$

Medina $0,1,1 \quad 5(2,8)$

Medina $0,1,0 \quad 33(18,2)$

Medina $1,0,0 \quad 56(30,9)$

Béta-szög (fok)

$<70 \quad 118(65,2)$

$70-90 \quad 46(25,4)$

\begin{tabular}{l}
$>90$ \\
\hline
\end{tabular}

Beavatkozás előtti föág TIMI-áramlás (\%)

$\begin{array}{ll}0-1 & 16(8,8)\end{array}$

$2 \quad 21(11,6)$

$3144(79,6)$

Beavatkozás előtti oldalág TIMI-áramlás (\%)

$\begin{array}{ll}0-1 & 18(9,9)\end{array}$

$24(13,3)$

$3139(76,8)$

Radiális behatolás (\%) $153(84,5)$

\begin{tabular}{|l|l}
\hline $6 \mathrm{~F}$ használat $(\%)$ & $140(77,4)$
\end{tabular}

Elötágítás (\%)

\begin{tabular}{l|l}
\hline Főág & $166(91,7)$
\end{tabular}

Oldalág

$11(6,1)$

Beavatkozás hossza (percben)

$39,6 \pm 23,8$

Főág-stentméret

Átmérő, mm

$3,2 \pm 0,27$

Hossz, mm

$28,0 \pm 9,1$

Oldalág-ballonméret

Átmérő, $\mathrm{mm} \quad 2,4 \pm 0,5$

Hossz, mm

$20,6 \pm 8,4$

$\mathrm{LAD}=$ bal mellső leszálló ág; $\mathrm{D}$ = diagonális ág; $\mathrm{PD}=$ posterior descendens artéria; $\mathrm{PL}=$ posterolateralis oldalág; $\mathrm{TIMI}=$ thrombolysis in myocardial infarction

meghaladó reziduális átmérőszűkület ábrázolódott, így 19 (10,5\%) esetben kiegészítő második stentimplantációra volt szükség az oldalágban. A főágban proximális stent edge-nél disszekció 3 (1,7\%) esetben, míg disztálisan 7 (3,9\%) esetben fordult elő, ezen eseteknél szükséges volt a disszekciót egy második endoprotézissel
3. TÁBLÁZAT. Közvetlen procedurális eredmények ( $n=181)$

\begin{tabular}{|c|c|}
\hline Sikeres procedúra (\%) & $180(99,5)$ \\
\hline \multicolumn{2}{|l|}{ Oldalágvesztés (\%) } \\
\hline Átmeneti & $7(3,9)$ \\
\hline Végleges & $1(0,5)$ \\
\hline \multicolumn{2}{|l|}{$\begin{array}{l}\text { Oldalág TIMI áramlása a föág stentelése } \\
\text { után (\%) }\end{array}$} \\
\hline $0-2$ & $12(6,6)$ \\
\hline 3 & $169(93,4)$ \\
\hline \multicolumn{2}{|l|}{ Disszekció (\%) } \\
\hline Proximális stent edge (C-F típusú) & $3(1,7)$ \\
\hline Disztális stent edge (C-F típusú) & $7(3,9)$ \\
\hline \multicolumn{2}{|l|}{ Oldalág ostium } \\
\hline A- és B-típusú & $8(4,4)$ \\
\hline C-F-típusú & $7(3,9)$ \\
\hline Oldalág-stentelés (\%) & $19(10,5)$ \\
\hline $\mathrm{T}$ and protrusion & $8(42,1)$ \\
\hline Culotte & $7(36,9)$ \\
\hline Reverse crush & $2(10,5)$ \\
\hline Mini stent-crush & $2(10,5)$ \\
\hline Jailed-ballon vagy drótbeszorulás (\%) & $0(0,0)$ \\
\hline
\end{tabular}

fedni. Az oldalágballont és -drótot mind a 181 beavatkozás során sikerült beszorulás, vagy károsodás nélkül eltávolítani.

A 4. táblázatban láthatók az angiográfiás jellemzők, a szükületek mértékének és a föág, valamint az oldalág közti béta-szögnek a meghatározása (vizuális becsléssel). Általános bevonási kritériumként az oldalág ostium legalább 20\%-os szükületét vettük; az eredések átmérőszükületeinek átlagértéke szignifikáns $(48,2 \% \pm 18,4 \%)$ volt, a stenosis mértéke jelentősen csökkent posztprocedurálisan $(p=0,04)$, míg a disztális föág szegmens és az oldalág közötti béta-szög jelentősen nem változott $(p=0,58) .2$ esetben az operatőr nem használt azonos projekciót a beavatkozás végén, így a szükületeket és a béta-szög nagyságát nem tudtuk megítélni.

A 11. ábra bemutatja a "highway oldalágcsatorna” jelentőségét az oldalágkezelés jó angiográfiás eredményének biztosításában, amelyen keresztül az oldalágba juttatott stentet a föágstent ballonja „mögé”, azt csak minimálisan az oldalág ostiuma felett indítva implantáltuk.

\section{Megbeszélés}

\section{A simplified highway-technika alkalmazása katéteres centrumunkban}

A táblázatokban feltüntetett eredményeink alapján kijelenthetjük, hogy az SHW-technikát magas posztprocedurális sikeraránnyal tudtuk alkalmazni, optimális oldalágvédéssel és megfelelő angiográfiás eredménynyel. 19,9\%-ban ACS-ben, 28,2\%-ban valódi bifurkációs szükületeknél is optimális eredményt kaptunk. Mind 
4. TÁBLÁZAT. A procedúra angiográfiás elemzése (vizuális becsléssel)

\begin{tabular}{c|c|c|}
$\begin{array}{c}\text { Baseline } \\
(n=181)\end{array}$ & $\begin{array}{c}\text { Posztpro- } \\
\text { ced. } \\
(n=179)\end{array}$ & $p$ \\
\hline
\end{tabular}

Főág proximális szegmens

\begin{tabular}{|c|c|c|c|}
\hline Átmérőszűkület (\%) & $72,5 \pm 22,1$ & $5,2 \pm 2,6$ & $<0,001$ \\
\hline \multicolumn{4}{|c|}{ Főág disztális szegmens } \\
\hline Átmérőszűkület (\%) & $51,6 \pm 22,4$ & $12,6 \pm 11,4$ & $<0,01$ \\
\hline \multicolumn{4}{|l|}{ Oldalág ostium } \\
\hline Átmérőszűkület (\%) & $48,2 \pm 18,4$ & $30,2 \pm 12,3$ & $=0,04$ \\
\hline Béta-szög (fok) & $68,7 \pm 21,3$ & $64,4 \pm 23,8$ & $=0,58$ \\
\hline
\end{tabular}

A szöget a két ér első 5-10 mm-es szakaszának középvonalában mértük. Kétmintás T-próba eredményei

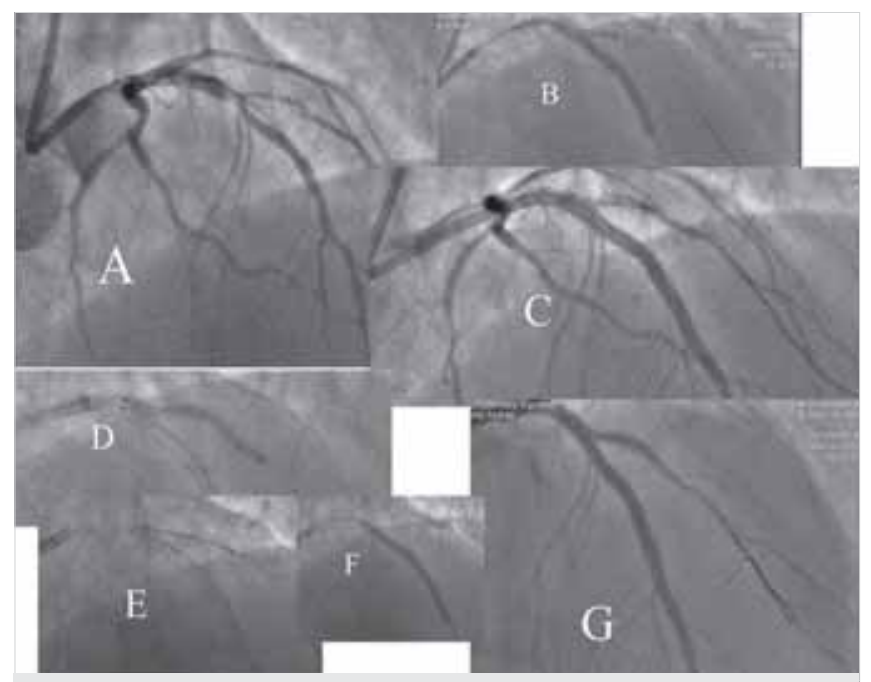

11. ÁBRA. Mini stent-crush stentelési technika. Medina 1,0,1 LAD-diagonális oldalág valódi bifurkációs szűkülete (A). Szimultán stentimplantáció a föágban és balloninfláció (SHW) az oldalágban (B), ennek eredményeként C-típusú disszekció alakult ki az oldalág eredésében (C), ezért a highway oldalág-csatornát feltágítottuk, miközben a föágstent ballonját a helyén hagytuk (D). Ezen "highway oldalág-csatornán” keresztül vittük ki az oldalágstentet a korábban kihelyezett főág stent alá (E), majd az oldalágballon és drót eltávolítása után a főágstent-ballonnal crush-oltuk az oldalágstentet (F) Végül újradrótozás után KBI és POT következett. Záró angiográfián optimális eredményt kaptunk (G)

LM-lézióknál, vagy nem LM bifurkációs szűkületeknél, különböző, akár lapos béta-szög esetében is sikerült a végleges oldalágvesztést kiküszöbölni (1-3. táblázat).

Az SHW alkalmazása csak válogatott esetekben jöhetett szóba, ugyanis nem minden bifurkációs szűkülettel rendelkező betegnél várható, hogy ez az optimális eljárás. Az operatőr szubjektív véleménye alapján néhány esetben nincs szükség az SHW alkalmazására az oldalágvédés során, vagy tervezetten 2-stent stratégiát kell választani. Eseteink 84,5\%-ában sikerült radiális behatolásból végezni a beavatkozást, amely lehetővé tette, hogy 6Fr-es felvezető katétert használjunk az esetek 77,4\%-ában, így azt mondhatjuk, hogy ezen technika szinte teljesen 6Fr kompatibilis. Ezt az oldalágvédési technikát viszonylag magas arányban $(28,2 \%)$ tudtuk valódi bifurkációs lézióknál (oldalágeredésben is legalább $50 \%$-ot meghaladó átmérőszűkület) is sikeresen alkalmazni (2. táblázat). A 4. táblázatban összefoglalt posztprocedurális eredmények alapján azt mondhatjuk, hogy a legtöbb esetben sikerült elkerülnünk a jelentős plakk-, illetve carina shift kialakulását. Ezt támasztja alá az oldalág ostialis reziduális szükületének $30 \%$ körüli volta, amely nem tủnhet optimálisnak, de ezen szűkületek szinte kivétel nélkül rövidek, az irodalomban is alátámasztottan funkcionálisan nem szignifikánsak. Előtágítás alkalmazására nem volt egyértelmű javaslat a beavatkozás leírásában, így annak szükségességéről az operatőr szubjektíven dönthetett, így a főágat 166 $(91,7 \%)$ esetben tágítottuk elő, míg az oldalágat csak 11 (6,1\%) alkalommal. Általánosságban, amennyiben nem súlyosan ateroszklerotikus oldalágról van szó, akkor az előtágítás nem javasolt, mert magasabb arányban alakulhat ki disszekció ( $\mathrm{C}-\mathrm{F}$ típus) benne, amely második stent behelyezését teszi szükségessé, pedig ezen technika is pont ennek elkerülésére hivatott. $A 181$ intervenció során 7 esetben (3,9\%) történt ilyen jellegü disszekció az oldalág eredésénél (3. táblázat).

A laposabb béta-szög a szuboptimális eredmény meghatározója, amely a mi eseteink között is gyakori volt (1. táblázat). Ilyenkor gyakrabban fordulhat elő restenosis vagy trombózis a turbulens áramlás, alacsony endothelialis nyíróerő és trombocitaaktiváció következtében. A 181 esetnél átlagban $68,7^{\circ}$-os volt a föág és az oldalág közti szög, amely magasabb kockázatot jelentett a nemkívánatos posztprocedurális események kialakulásában. A béta-szög laposabbá válása elősegítheti az oldalág elzáródását a plakk-, vagy carina shift által; anyagunkban a beavatkozások során a béta-szög szignifikáns mértékben nem változott (4. táblázat), így eseteinkben ez is hozzájárulhatott a procedurális sikerhez.

\section{A simplified highway-technikával kapcsola-} tos lehetséges problémák és előnyök

A jó posztprocedurális áramlási arány és viszonylag kismértékű reziduális stenosis alapján úgy véljük, hogy az SHW-technika egy széles körben, különböző típusú szűkületek esetén is alkalmazható eljárás. Ezen technika fő előnye, hogy a beavatkozás során folyamatos hozzáférést tudunk biztosítani az oldalághoz, így ennek megfelelő kezelést tudunk alkalmazni. Elméletileg komplikációként jelentkezhet az oldalágballon beszorulása, amelyet egy esetben sem tapasztaltunk. A beavatkozások során az oldalágballont sikerült nagyobb húzóerő kifejtése nélkül eltávolítani, annak a megfontolásnak köszönhetően, hogy az oldalág-védőballont szimultán infláltuk. Ez a kisebb (a nominális fele) nyomás az oldalág eredésénél kialakult disszekció esélyét csökkenti a nem jelentős barotrauma által. Beteganyagunkban hét esetben fordult elő nagyobb fokú oldalág-disszekció, de az ő esetükben relatíve hosz- 
szú és súlyosan meszes lézió volt jelen. Itt még kisebb semi-compliant ballont kellett volna alkalmazni, hogy elkerüljük az ehhez hasonló komplikációkat. A stent megfelelő appozíciója érdekében minden intervenciót rövid NC-ballonnal végzett POT-tal egészítettünk ki.

Az SHW-technika esetleges szuboptimális eredménye abból származhat, hogy a stenten proximálisan túlérő oldalágballon a proximális szegmens sérülését, diszszekcióját okozhatja. Mi 3 esetben tapasztaltunk manifeszt disszekciót, amikor a proximális fóágba újabb stentet kellett implantálni. Ez a technika limitációját is jelenti, úgy is fogalmazhatnánk, hogy a megfelelő léziót kell kiválasztani, ahol a proximális épnek látszó szakasz elegendő hosszúságú.

\section{Limitációk}

A vizsgálatunknak számos limitációja van. A legfontosabb, hogy a technikára alkalmas szükületek kritériumai nem voltak pontosan definiálva (pl. mi a meszes szükület maximális foka). Részlegünkön az operatőrök nem egységesen használják ezt a technikát, minden bifurkációs $\mathrm{PCl}$ alkalmával az operatőrre van bízva, hogy alkalmazza-e az SHW-t vagy hagyományos megoldást választ. Arról nem vezettünk prospektív kérdőívet, hogy pontosan milyen léziótulajdonságok befolyásolják őket a döntéshozatalban, hogy melyik eljárást részesítik előnyben. Hosszú távú klinikai eredményeink vizsgálata jelenleg is folyamatban van intézetünkben. Kisebb limitációnak számít, hogy nem alkalmazunk kvantitatív koszorúér-angiográfiát és akut esetekben - ahol a kezelt erek átmérőit nem lehet helyesen megítélni - kevés tapasztalatunk van a technikával kapcsolatban. Valamint az ér meszességének mértékét sem számszerüsítettük, amely rizikótényezőként szerepelhet az oldalágeredés disszekciójában, ezáltal az oldalág stentelésében is.

\section{Következtetés}

Következtetésként azt mondhatjuk, hogy a simplified highway-technika alkalmazása a provizionális oldalágstentelés során megfelelően kiválasztott léziók esetén alkalmazható és magas procedurális sikert eredményezett. Az általunk vizsgált 180 beteg esetében ezen technika használata során meglehetősen kis arányban fordult elő oldalág-elzáródás, valamint második stent behelyezésére is kevés esetben volt szükség. Kijelenthető, hogy a koszorúér bifurkációs szűkületeinek tervezett PSBS kezelése során az SHW alkalmazása előnyös választás; ugyanakkor további klinikai vizsgálatok szükségesek a hosszabb távú eredményesség ellenőrzésére.

\section{Nyilatkozat}

A szerzők kijelentik, hogy a közlemény megírásával kapcsolatban nem áll fenn velük szemben pénzügyi vagy egyéb lényeges összeütközés, összeférhetetlenségi ok, amely befolyásolhatja a közleményben bemutatott eredményeket, az abból levont következtetéseket vagy azok értelmezését.

Irodalom

1. Aminian A, Dolatabadi D, et al. Small balloon inflation over a jailed wire as a bailout technique in a case of abrupt side branch occlusion during provisional stenting. J Invasive Cardiol 2010; 22 (9): 449-452.

2. Bhargava B, Waksman R, et al. Clinical outcomes of compromised side branch (stent jail) after coronary stenting with the NIR stent. Catheter Cardiovasc Interv 2001; 54 (3): 295-300. DOI: $10.1002 / \mathrm{ccd} .1287$

3. Burzotta F, Trani C. Jailed balloon protection and rescue balloon jailing tech niques set the field for safer bifurcation provisional stenting. Int J Cardiol 2015; 201 . 376-377. DOI: 10.1016/j.ijcard.2015.06.185

4. Burzotta F, Trani C, et al. Jailed balloon protection: a new technique to avoid acute side-branch occlusion during provisional stenting of bifurcated lesions. Bench test report and first clinical experience. Eurolntervention 2010; 5 (7): 809 813. DOI: 10.4244/eijv5i7a135

5. Catakoglu $A B$, Aytekin $\mathrm{V}$. The Highway Technique: a new stenting technique to treat coronary bifurcation lesions. Eurolntervention 2010; 5 (7): 821-825. DOI: 10.4244/eijv5i7a137

6. Cayli M, Seker T, et al. A Novel-Modified Provisional Bifurcation Stenting Technique: Jailed Semi-Inflated Balloon Technique. J Interv Cardiol 2015; 28 (5): 420429. DOI: $10.1111 /$ joic. 12225

7. Chaudhry EC, Dauerman KP et al. Percutaneous coronary intervention for major bifurcation lesions using the simple approach: risk of myocardial infarction. J Thromb Thrombolysis 2007; 24 (1): 7-13. DOI: 10.1007/s11239-006-0004-6

8. Depta JP, Patel Y, et al. Long-term clinical outcomes with the use of a modified provisional jailed-balloon stenting technique for the treatment of nonleft main coronary bifurcation lesions. Catheter Cardiovasc Interv 2013; 82 (5): E637-646. DOI: $10.1002 /$ ccd. 24778

9. Dzavik V, Kharbanda R, et al. Predictors of long-term outcome after crush stenting of coronary bifurcation lesions: importance of the bifurcation angle. Am Heart J 2006 ; 152 (4): 762-769. DOI: 10.1016/j.ahj.2006.04.033

10. Fajadet $\mathrm{J}$, Chieffo $\mathrm{A}$. Current management of left main coronary artery disease. Eur Heart J 2012; 33 (1): 36-50b. DOI: 10.1093/eurheartj/ehr426

11. Hildick-Smith D, Behan MW, et al. The EBC TWO Study (European Bifurcation Coronary TWO): A Randomized Comparison of Provisional T-Stenting Versus a Systematic 2 Stent Culotte Strategy in Large Caliber True Bifurcations. Circ Cardiovasc Interv 2016; 9 (9). DOI: 10.1161/CIRCINTERVENTIONS.115.003643

12. Kang SJ, Mintz GS, et al. Preintervention angiographic and intravascular ultrasound predictors for side branch compromise after a single-stent crossover technique. Am J Cardiol 2011; 107 (12): 1787-1793. DOI: 10.1016/j.amjcard.2011.02.323 13. Lassen JF, Holm NR, et al. Percutaneous coronary intervention for coronary bifurcation disease: $11^{\text {th }}$ consensus document from the European Bifurcation Club. Eurolntervention 2016; 12 (1): 38-46. DOI: 10.4244/EIJ-D-18-00357

14. Lefevre $T$, Darremont $O$, et al. Provisional side branch stenting for the treatment of bifurcation lesions. Eurolntervention 2010; 6 (Suppl J): J65-71. DOI: 10.4244/EIJV6SUPJA11

15. Lefevre T, Morice MC, et al. Influence of technical strategies on the outcome of coronary bifurcation stenting. Eurolntervention 2005; 1 (1): 31-37. DOI: 10.15420/ icr.2013.8.2.96

16. Medina A, Suarez de Lezo J, et al. [A new classification of coronary bifurcation lesions]. Rev Esp Cardiol 2006; 59 (2): 183

17. Meier B, Gruentzig AR, et al. Risk of side branch occlusion during coronary angioplasty. Am J Cardiol 1984; 53 (1): 10-14. DOI: 10.1016/0002-9149(84)90675-1 18. Milasinovic $D$, Wijns $W$, et al. Step-by-step manual for planning and performing bifurcation PCl: a resource-tailored approach. Eurolntervention 2018; 13 (15): e1804-e1811. DOI: 10.4244/EIJ-D-17-00580

19. Morice MC, Serruys PW, et al. Outcomes in patients with de novo left main disease treated with either percutaneous coronary intervention using paclitaxel-eluting stents or coronary artery bypass graft treatment in the Synergy Between 20. Percutaneous Coronary Intervention with TAXUS and Cardiac Surgery (SYNTAX) trial. Circulation 2010; 121 (24): 2645-2653. DOI: 10.1161/CIRCULATIONAHA.109.899211

20. Pan $M$, Romero $M$, et al. Inverted crush technique for uncrossable side branch occlusion during provisional side branch stenting: a new role for the jailed wire. Rev Esp Cardiol 2011; 64 (8): 718-722. DOI: 10.1016/j.jcin.2018.03.051

21. Saito S, Shishido K, et al. Modified jailed balloon technique for bifurcation lesions. Catheter Cardiovasc Interv 2018; 92 (3): E218-E226. DOI: 10.1002/ ccd. 27334

22. Schneider JE, Mann T, et al. Transradial Coronary Stenting: A United States Experience. J Invasive Cardiol 1997; 9 (9): 569-574.

23. Seo JB, Shin DH, et al. Predictors for Side Branch Failure During Provisional Strategy of Coronary Intervention for Bifurcation Lesions (from the Korean Bifurcation Registry). Am J Cardiol 2016; 118 (6): 797-803. DOI: 10.1016/j.amjcard.2016.06.049

24. Sgueglia GA, Todaro $D$, et al. Complexity and simplicity in percutaneous bifurcation interventions. Eurolntervention 2010; 6 (5): 664-665. DOI: 10.4244/EIJV6I5A111

25. Singh J, Patel Y, et al. A modified provisional stenting approach to coronary bifurcation lesions: clinical application of the jailed-balloon technique. J Interv Cardiol 2012; 25 (3): 289-296. DOI: 10.1111/j.1540-8183.2011.00716.x

26. Sishido K. Modified Jailed Balloon Technique: A Novel Technique to Avoid Side Branch Occlusion Regarding with Percutaneous Coronary Intervention for Bifurcation Lesions. Eurolntervention 2016.

27. Weber $\mathrm{C}$, Noels $\mathrm{H}$. Atherosclerosis: current pathogenesis and therapeutic options. Nat Med 2011; 17 (11): 1410-1422. DOI: 10.1038/nm.2538 